\title{
"A literatura é o lugar das possibilidades": entrevista com Ana Maria Gonçalves
}

\author{
Por Graziele Frederico, ${ }^{1}$ Lúcia Tormin Mollo ${ }^{2}$ e Paula Queiroz Dutra ${ }^{3}$
}

Ana Maria Gonçalves (Ibiá, 1970) atuou como publicitária até passar a se dedicar integralmente à literatura. Estreou como escritora em 2002, com a publicação de Ao lado e à margem do que sentes por mim. Em 2006, lançou Um defeito de cor, romance que ganhou o prêmio Casa de Las Americas em 2007 e a projetou na carreira de escritora. Depois de morar alguns anos em New Orleans, atualmente mora em São Paulo, onde está finalizando um novo livro de ficção, Quem É Josenildo?

Qual a sua relação com a literatura? Por que você escreve, afinal?

Acho que o motivo de eu escrever é uma pergunta que vai me acompanhar para sempre, porque não há uma resposta que dure muito tempo. Cada texto - seja qual for o tamanho ou gênero - nasce de uma necessidade de pesquisar e escrever sobre algo, que é substituída por outra assim que se torna experiência. Talvez, então, a resposta mais sincera seja esta: escrevo pela busca de experiências que me permitam entender um pouco o mundo a meu redor, estejam elas relacionadas entre si ou não.

Você acha importante se dizer autora negra dentro do campo literário brasileiro? O rótulo demarca ou aprisiona sua trajetória?

Acredito que escrevo, principalmente, a partir de duas identidades que, em mim, se complementam: mulher e negra. É a partir desses dois lugares que experimento o mundo, e é também neles que busco as histórias que me interessa contar, esperando que não sejam lugares limitadores, mas de inclusão e colaboração com o projeto de narrativa da experiência humana.

\footnotetext{
${ }^{1}$ Doutoranda em Literatura na Universidade de Brasília (UnB), Brasília, DF, Brasil. E-mail: grafrederico@gmail.com

${ }_{2}^{2}$ Doutoranda em Literatura na Universidade de Brasília (UnB), Brasília, DF, Brasil. E-mail: ltorminmollo@gmail.com

${ }^{3}$ Doutoranda em Literatura na Universidade de Brasília (UnB), Brasília, DF, Brasil. E-mail: qpaulad@gmail.com
} 
O racismo presente na sociedade brasileira afeta a sua produção? De que modo?

Racismo é o tema sobre o qual me interessa escrever; não como fato isolado, mas como realidade intrínseca desde sempre à sociedade brasileira e que deve ser lido na sua dimensão coletiva.

Quais temas ultimamente Ihe interessam, Ihe instigam a escrever? Ou é uma forma que a leva a uma ideia? Por onde começa a escrita?

Não tem fórmula. A necessidade de escrita às vezes vem de uma ideia para abordagem de um determinado tema, de uma frase, de uma experiência própria ou observada, de uma personagem real ou fictícia, de uma notícia, de uma memória etc. Mas está sempre relacionada a um não entendimento, a algo que não se encaixa numa versão que tenta se apresentar como oficial. Escrevo para, através de vários personagens, analisar algo sob pontos de vista diferentes.

Qual relação de sua escrita com suas experiências (pensando em raça, gênero, classe, moradia, geração etc.)?

Para mim, pelo menos, é impossível desvincular uma coisa de outra. É a partir desses lugares (raça, gênero, classe, moradia, geração etc.) que estou no mundo. Não que isso me impeça de escrever a partir de outros lugares, mas será sempre em relação ao lugar a partir do qual vejo o mundo e sou vista por ele.

\section{Qual o peso que o machismo ainda tem no Brasil atual?}

Acredito que o machismo continua sendo um dos pilares das relações sociais e afetivas no Brasil e no mundo, afetando igualmente homens e mulheres, embora as consequências mais perigosas e limitadoras sejam para as mulheres.

\section{É possível desvincular a produção literária de um ato político?}

Acredito que toda manifestação artística, e não apenas a literária, é marcada pela ideologia; inclusive ou até principalmente aquela que diz não ter ideologia nenhuma. A minha, por consequência de quem sou, e por escolha, é política, e uma de minhas maiores preocupações é 
conduzi-la de maneira que, inclusive, dialogue com quem tem posições diferentes das minhas.

Em diversos trabalhos de autoria negra vemos o corpo como uma dimensão muito presente. O que esse corpo significa em sua produção? A que ele serve?

Foi através do corpo, e só por causa dele, que o ser escravizado foi introduzido nas Américas, e é claro que isso tem uma consequência que se manifesta ainda nos dias atuais. No negro da diáspora tudo passa pelo corpo. A partir dele tento pensar as forças antagônicas que ele representa: força $x$ fraqueza, visibilidade $x$ invisibilidade, medo $x$ coragem, atração $x$ repulsa etc. e encontrar um lugar onde ele possa ser ouvido e entendido fora dos limites que lhe são impostos pela sociedade.

Qual a importância e o papel da literatura num país com tamanhas desigualdades sociais?

Eu encaro a literatura como o lugar das possibilidades. Numa folha de papel, ou qualquer outro meio, tudo é possível, inclusive adentrar em outros universos com os quais nunca tivemos ou teremos contato direto. Exercer a alteridade e repensar privilégios, oportunidades e inclusão, tanto de dentro quanto de fora do "sistema". Acho que essa capacidade de fazer pensar, sonhar, viver outras realidades é, não uma obrigação, mas uma das possibilidades mais interessantes da literatura.

Quem são seus leitores? Qual leitor você imagina quando escreve e quem você sabe que lê seus livros?

Não sei. Não acho que meus leitores tenham um perfil único, o que é bem interessante para mim, porque recebo comentários com as mais diversas experiências de leitura, de acordo com a capacidade, a vivência, a formação, que são únicas de cada ser humano. Primeiro, acho que escrevo para a leitora que eu sou, por não ter encontrado um livro ou uma história que satisfizesse minha curiosidade e necessidade de compreensão de um determinado assunto. É uma experiência pessoal que se transforma em universal a partir do momento em que tal assunto pode vir a ser do interesse de outros leitores. Para tanto, tento fazer da sinceridade com que lido com determinadas questões uma 
maneira de despertar inquietação e curiosidade, para que novas contribuições sejam feitas.

É possível vislumbrar uma melhora na inserção no mercado editorial a partir de novas mídias, como as redes sociais? Isso tem alguma influência na sua escrita?

Sou da última geração que conheceu o mundo pré-internet, e isso tem influência no meu modo de processar informações e lidar com o tempo. Comecei a escrever ficção em blogs, que me levaram ao mercado editorial "tradicional". Tenho então uma relação de fascínio e de ansiedade com as redes sociais, porque é muita coisa acontecendo ao mesmo tempo, e fujo delas quando preciso escrever. Necessito de silêncio para poder pensar melhor, ao mesmo tempo que acredito que já não é mais possível pensar o mundo contemporâneo sem prestar atenção no que acontece nas redes. É uma relação ambígua, que acredito que as gerações depois da minha saberão resolver de uma forma mais tranquila, porque, com certeza, o mundo, e não apenas o mercado editorial, é outro depois que boa parte de seus habitantes ganharam o direito de manifestação. Se é um mundo - ou um mercado - melhor e mais inclusivo, acredito ser ainda cedo para saber. Não sei se tem influência na minha escrita, mas com certeza o tem nas coisas sobre as quais escrevo, principalmente porque ele me dá a possibilidade de ouvir mais vozes, contar com mais experiências.

Se fosse possível criar uma imagem do Brasil a partir dos escritores contemporâneos, qual imagem você acha que teríamos representada?

Resumindo: homem, branco, classe média ou média alta, hétero, vivendo nos grandes centros econômicos.

Qual sua análise sobre um aumento dos mais diversos tipos de intolerância (religiosa, de gênero, racial, social) no país? Vivemos tempos mais violentos?

Não sei se é um aumento ou apenas a fricção com pensamentos e pessoas que desafiam o status quo. Tenho a sensação de que tudo sempre esteve ali, adormecido, porque não era confrontado. Sim, vivemos tempos violentos, mas não mais violentos do que o tempo do silenciamento. Acredito, inclusive, numa escalada ainda maior do confronto, até que o 
choque de interesses entre os que lutam pela inclusão e os que lutam para manter seus privilégios encontre um ponto de equilíbrio.

Qual importância da liberdade e democracia para a literatura?

São fundamentais, porque garantem que as mais diversas vozes, mesmo antagônicas, sejam levadas em conta na construção não apenas da cultura mas também da História de um povo e de uma época.

Quais os/as autores/as, pensadores/as, pessoas têm influência na sua obra?

Não consigo destacar ninguém especificamente, mesmo porque fui e continuo sendo uma leitora - a partir de onde me tornei escritora bastante eclética. Fujo de leitura de ficção quando estou escrevendo, porque certos autores têm uma escrita com a qual é fácil eu me contaminar. Eu me considero mais uma contadora de estórias que uma escritora; então, os que mais me prendem são os que também vão pelo mesmo caminho. Mas se há alguém a quem posso destacar, é minha mãe, que foi quem me ensinou o prazer da leitura e quem continua sendo, até hoje, a minha primeira leitora, a de confiança. 